\title{
THE EVALUATION OF MUSCULOSKELETAL SYSTEM TUMORS AND TUMOR LIKE LESIONS IN THRACE REGION
}

\author{
Ece Şenyiğit ${ }^{1}$, Begüm Söyleyici ${ }^{1}$, Nur Gülce İşkan ${ }^{1}$, Hilal Sena Çifcibaş ${ }^{1}$, Aslı Göztepe ${ }^{1}$, Mert Çiftdemir ${ }^{2}$ \\ ${ }^{1}$ Trakya University School of Medicine, Edirne, TURKEY \\ ${ }^{2}$ Department of Orthopedics and Traumatology, Trakya University School of Medicine, Edirne, TURKEY
}

\section{ABSTRACT}

Aims: The aim of this study is to evaluate the data belonging to patients who were diagnosed with benign or malignant soft tissue and bone tumors and tumor-like lesions evaluated by musculoskeletal tumor study group of Trakya University Faculty of Medicine in between January 2013 and June 2017 and the relationship between the frequency of benign, malignant bone and soft tissue tumors and tumor-like lesions, with the patients' age and gender.

Methods: The data of 687 patients who were evaluated by the musculoskeletal tumor study group of Trakya University Faculty of Medicine between January 2013- June 2017 were analyzed retrospectively. All of the data was analyzed by using SPSS. Chi-square analysis was used to obtain categorical data in order to point out the distribution of age and gender of patients with musculoskeletal system tumors and tumor-like lesions.

Results: The number of patients over the period from January 2013 to June 2017 was 687 . The number of patients who were evaluated by biopsy and acquired histopathologic confirmation of their condition was 341 . The mean of patients' ages was $44.3 \pm 21.4$ (4-92). Among 341 patients, 106 (47.1\%) patients were female and 119 (52.9\%) patients were male. The mean of females' ages was $43.7 \pm 20.4$ (4-92). The mean of males' ages was $44.7 \pm 22.4$ (5-90).

Conclusion: Benign bone and soft tissue tumors were more common than malignant tumors. Benign bone tumors were predominantly seen in young adults. Our results was consistent with the literature however due to some patients who did not need a pathological sampling, our sample size was smaller than intended. With better archived information, more consistent results could be obtained in further studies.

Keywords: Tumor, bone, tissue, epidemiology

\section{INTRODUCTION}

The musculoskeletal system tumors and tumor-like lesions are categorized as benign, malignant tumors and tumor-like lesions. Osteoid osteoma, osteoblastoma, osteoma, osteochondroma, enchondroma, giant cell tumors are considered as benign bone tumors whereas osteosarcoma, Ewing's sarcoma and chondrosarcoma are considered as malignant bone tumors. Lipoma, rhabdomyoma, leiomyoma, hemangioma etc. are regarded as benign soft tissue tumors whereas liposarcomas, fibrosarcomas, leiomyosarcomas etc. are regarded as malignant soft tissue tumors. There are also tumor-like lesions such as bone cysts (1).
Malignant bone tumors are naturally primary or metastatic (2). Bone is a common place for metastasis of visceral cancers $(3,4)$. There are five visceral organ cancers which commonly metastasize to the bones. These are respectively lung, breast, prostate, kidney and thyroid cancers. In addition, bones can be affected by cancers that originate from the reticuloendothelial system and metastasize such as multiple myeloma. When cancer metastasizes on the bones, they usually become more susceptible to pathologic fractures. Since not all bone tumors are symptomatic, the incidence is frequently higher than detected rates (4).

Studies show that osteochondroma is the most common tumor of the bone. Lower limbs are the most common site for bone tumors. Other common areas are 
pelvis and upper limbs (1). The most common primary malignant tumor of the bone is osteosarcoma and this tumor shows a bimodal age distribution which has its first peak at the 2nd decade and the second peak at the 7 th decade. Chondrosarcoma is also one of the malignant tumors and the patients' ages are generally greater than 50 years (1).

Benign bone tumors are more common than malignant bone tumors and they are mostly seen in children and young adults (5).

On the other hand, some lesions imitate bone and soft tissue tumors. These are tumor-like lesions. Tumor-like lesions can be described as bone lesions which are not caused by a tumoral process. These are infections such as osteomyelitis, Brodie abscess and cystic lesions such as simple bone cysts (1). They are also kept in mind in differential diagnosis.

The aim of this study is to appraise the data belonging to patients who were evaluated regarding the musculoskeletal study group of Trakya University Faculty of Medicine between January 2013 and June 2017 and the relationship between the frequency of benign and malignant musculoskeletal system tumors and tumor-like lesions with the patients' age and gender.

\section{MATERIAL AND METHODS}

This study was approved by Scientific Research Ethics Committee of Trakya University Faculty of Medicine. In this study, the data of all patients who were evaluated by the musculoskeletal study group of Trakya University Faculty of Medicine between January 2013- June 2017 were analyzed retrospectively. The number of the patients was 687. Informed consent was obtained from all of the subjects. Age and gender data of the patients who were pre-diagnosed with musculoskeletal system tumors and tumor-like lesions were obtained from General Archive Unit of Trakya University Hospital and only known by researchers. After data collection, pathological diagnoses were categorized into two basic classifications as bone tumors and soft tissue tumors. In both sections, three categories were identified as malignant, benign and tumor-like lesions. In the study; liposarcoma, periosteal osteosarcoma, adenocarcinoma, chondrosarcoma, metastatic carcinoma and myxoid liposarcoma were considered as malignant tumors. Lipoma, osteochondroma, enchondroma, schwannoma, traumatic and Morton's neuroma, giant cell tumor of the tendon sheath, osteoid osteoma, plasmacytoma, keratinous cyst, enchondromatosis, fibroma of the tendon sheath, and intraosseous lipoma were added to the category of benign tumors. Simple bone cyst and ganglion cyst were categorized as tumor-like lesions.

All of the data were analyzed using IBM SPSS 20.0. In this study; numbers, percentages, arithmetic mean \pm standard deviation (minimum-maximum) were used as descriptive statistics. Chi-square analysis was used to obtain categorical data in order to point out the distribution of age and gender of patients with musculoskeletal system tumors and tumor-like lesions. A p-value $<0.05$ was set for the statistically significance.

\section{RESULTS}

The mean number of patients with a pre-diagnosis of musculoskeletal system tumor over the period from January 2013 to June 2017 was 687.347 (50.5\%) of the patients were male and $340(49.5 \%)$ patients were female. Table 1 shows the numbers of patients who are pre-diagnosed with musculoskeletal system tumors and tumor-like lesions and also the number of patients whose pathology reports demonstrate the final diagnosis available in the system according to years. The number of patients who have pathology reports was 341 . The mean of patients' ages was 44.3 \pm 21.4 (4-92). Among 341 patients, $106(47.1 \%)$ patients were female and 119 (52.9\%) patients were male. The mean age of female patients was $43.7 \pm 20.4$ (4-92). The mean age of male patients was $44.7 \pm 22.4$ (5-90). Table 2 summarizes the demographic data of genders. There is no statistically significant difference found between genders ( $p>0.05)$. Consistent with the data of patients with reports, the number of soft tissue tumors was 72.146 patients were found as diagnosed with bone tumors and 6 patients had tumor-like lesions. Among all the data of tumor and tumor-like lesions, the type of the lesion was not written on one patient's pathology report. There were 142 benign tumors, 70 malignant tumors and 13 missing data for tumor type in pathology reports. Table 3 shows the distribution of tumors and tumor-like lesions according to years. Table 4 summarizes the variants of tumors and means of ages (Table 4 and 5). There is no statistically significant difference between the mean of ages in different types of tumors ( $p>0.05)$. 
Table 1: Numbers of pre-diagnosed and diagnosed patients.

\begin{tabular}{|l|c|c|c|c|c|c|}
\hline & $\mathbf{2 0 1 3}$ & $\mathbf{2 0 1 4}$ & $\mathbf{2 0 1 5}$ & $\mathbf{2 0 1 6}$ & $\mathbf{2 0 1 7}$ & Total \\
\hline $\begin{array}{l}\text { Number of pre- } \\
\text { diagnosed } \\
\text { patients (n) }\end{array}$ & 48 & 168 & 214 & 169 & 88 & 687 \\
\hline $\begin{array}{l}\text { Number of } \\
\text { pathology } \\
\text { reports (n) }\end{array}$ & 25 & 50 & 122 & 89 & 55 & 341 \\
\hline
\end{tabular}

Table 2: Distribution of tumors and ages.

\begin{tabular}{|l|c|c|c|}
\hline & Soft tissue tumors & Bone tumors & Tumor-like lesions \\
\hline Male (n) & 39 & 76 & 3 \\
\hline Female (n) & 33 & 70 & 3 \\
\hline $\begin{array}{l}\text { The mean of males' } \\
\text { ages (years) }\end{array}$ & 47.8 & 43.8 & 18.3 \\
\hline $\begin{array}{l}\text { The mean of females' } \\
\text { ages (years) }\end{array}$ & 50.5 & 41 & 35.7 \\
\hline
\end{tabular}

Table 3: Distribution of tumors and tumor-like lesions according to years.

\begin{tabular}{|l|c|c|c|c|c|c|}
\hline & \multicolumn{3}{|c|}{ Bone tumors (n) } & \multicolumn{2}{c|}{ Soft tissue tumors (n) } & Unidentified tumors $^{*}$ \\
\hline Year & $\begin{array}{c}\text { Malignant } \\
\text { tumors }\end{array}$ & $\begin{array}{c}\text { Benign } \\
\text { tumors }\end{array}$ & $\begin{array}{c}\text { Tumor-like } \\
\text { lesions }\end{array}$ & $\begin{array}{c}\text { Malignant } \\
\text { tumors }\end{array}$ & $\begin{array}{c}\text { Benign } \\
\text { tumors }\end{array}$ & \\
\hline $\mathbf{2 0 1 3}$ & 5 & 5 & 1 & 2 & 3 & - \\
\hline $\mathbf{2 0 1 4}$ & 13 & 17 & 1 & 14 & 11 & - \\
\hline $\mathbf{2 0 1 5}$ & 18 & 34 & 2 & 8 & 17 & 2 \\
\hline $\mathbf{2 0 1 6}$ & 5 & 13 & 2 & 4 & 10 & 4 \\
\hline $\mathbf{2 0 1 7}$ & 13 & 22 & 1 & 2 & 9 & - \\
\hline
\end{tabular}

'In 6 of the pathology reports, the diagnoses were given as 'soft tissue tumors' without any identification as malignant or benign.

Table 4: Numbers of patients and means of ages according to soft tissue and bone tumors.

\begin{tabular}{|l|c|c|c|c|}
\hline & \multicolumn{2}{|c|}{ Soft tissue tumors } & \multicolumn{2}{c|}{ Bone tumors } \\
\hline Benign (n/mean of ages) & 50 & 47.4 & 92 & 35.8 \\
\hline Malign (n/mean of ages) & 16 & 53.9 & 54 & 54.1 \\
\hline $\begin{array}{l}\text { Tumor-like lesions (n/mean } \\
\text { of ages) }\end{array}$ & - & - & 7 & 29.4 \\
\hline
\end{tabular}

Table 5: Numbers of patients and mean of ages according to benign and malign tumors.

\begin{tabular}{|l|c|c|c|c|c|c|}
\hline & \multicolumn{2}{|c|}{ Benign tumors } & \multicolumn{2}{c|}{ Malignant tumors } & \multicolumn{2}{c|}{ Tumor-like lesions } \\
\hline Male (n/mean of ages) & 74 & 37.6 & 40 & 60.1 & 4 & 24.8 \\
\hline $\begin{array}{l}\text { Female (n/mean of } \\
\text { ages) }\end{array}$ & 68 & 42.3 & 30 & 46.2 & 3 & 35.7 \\
\hline
\end{tabular}

\section{DISCUSSION}

Pathologic lesions in musculoskeletal tissue were grouped as tumor-like lesions, benign tumors and malignant tumors in this study. The data of 341 patients were analyzed and categorized as afore-mentioned. According to the results, bone tumors are more common than soft tissue tumors and benign tumors are more in number than malignant tumors in general.

The rate of tumors and tumor-like lesions was similar in both genders. In addition, the rate of bone tumors also did not show a significant difference in both genders. However, the studies of Kazi et al. (6) and Dabak et al. (7) showed that bone tumors are more common in males. The reason behind the difference between this study and the literature may be due to the number of patients. In the study of Kazi et al. (6), there are more male patients than this study. However, the results of this study are compatible with the literature according to the frequency of benign and malignant tumors. It is stated that benign bone tumors are more common than malignant tumors that is also valid for this study $(6,7)$.

According to the literature, benign bone tumors are more common in younger individuals (8). In this study, the mean age of patients with benign bone tumors was found 35.8 years that is younger by comparison with the mean ages found as of other tumors.

Dabak et al. (7) reported in their study that the frequency of bone tumors is more than soft tissue tumors which is also compatible with our study. Their study, which has the same methodology with our study has been conducted in the middle Black Sea region. Their study results show that benign and malignant tumors are more frequently seen in ages between 31-41 and 51-60 respectively (7). In our study, we found the mean age of patients with benign tumors is 39.9 years and the mean age of patients with malignant tumors is 53.1 years and they indicate that Trakya region also has similar results.

Dabak et al. (7) also reported the mean ages of bone and soft tissue tumors in their study. However, in our study, the mean ages of both types of tumors were found older than Dabak's results (7). The reason for this age gap might be relevant to the number of the patients evaluated.

Out of 687 patients who were evaluated by the council, there are only 341 patients whose diagnosis was confirmed by a pathological examination. Other patients 
who did not have any pathological report were evaluated through radiological screenings and clinical examinations. In that respect, numbers of the pathology reports are less than the total patient population. Therefore, the results of the study may not be sufficient to reflect the expected population.

As a conclusion, the data from our study showed that benign bone tumors and benign soft tissue tumors are more common than malignant forms. Moreover, in both genders, bone tumors are more seen than soft tissue tumors. Our results have both differences and similarities with the literature. In that respect, bone and soft tissue tumors not only have some certain characteristics but also have regional differences in frequency. With more data of these types of studies from different centers may provide effective data for the epidemiological research of bone and soft tissue tumors.

Ethics Committee Approval: This study was approved by Scientific Researches Committee of Trakya University School of Medicine.

Informed Consent: Written informed consent was obtained from the participants of this study.

Conflict of Interest: The authors declared no conflict of interest.

Author contributions: Concept: EŞ, BS, NGİ, HSÇ, AG, MÇ. Design: EŞ, BS, NGİ, HSÇ, AG, MÇ. Supervision: EŞ, BS, NGİ, HSÇ, AG, MÇ. Resources: EŞ, BS, NGİ, HSÇ, AG, MÇ. Materials: EŞ, BS, NGİ, HSÇ, AG, MÇ. Data collection and/or processing: EŞ, BS, NGİ, HSÇ, AG, MÇ. Analysis and/or Interpretation: EŞ, BS, NGİ, HSÇ, AG, MÇ. Literature Search: EŞ, BS, NGİ, HSÇ, AG, MÇ. Writing Manuscript: EŞ, BS, NGİ, HSÇ, AG, MÇ. Critical Review: EŞ, BS, NGİ, HSÇ, AG, MÇ.

Financial disclosure: The authors declared that this study received no financial support.

Editor-in-chief's Note: Five of the authors of this article, Ece Şenyiğit, Begüm Söyleyici, Nur Gülce İşkan, Hilal Sena Çifcibaşı, Aslı Göztepe are members of the editorial board of Turkish Medical Student Journal. However, they did not take place in any stage on the editorial decision of the manuscript. The editors who evaluated this manuscript are from another institutions.

\section{REFERENCES}

1.Rosenber AE. Kemikler, eklemler ve yumuşak doku tümörleri. In: Kumar V, Abbas AK, Aster JC, editors. Robbins Temel Patoloji. İstanbul: Nobel; 2013.p.774-81.
2. Bahk YW. Malignant tumors of bone. 5th ed. Combined Scintigraphic and Radiographic Diagnosis of Bone and Joint Diseases. Springer; 2017.

3. Coleman RE. Skeletal complications of malignancy. Cancer 1997;80:1588-94.

4. Lote K, Walloe A, Bjersand A. Bone metastasis: prognosis, diagnosis and treatment. Acta Radiol Oncol 1986;25:227-32.

5. Beckingsale T, Shaw C. Epidemiology of bone and soft-tissue sarcomas. Orthopaedics and Trauma 2015;29:182-8.

6. Kazi B, Syed A, Ayub A et al. Study of bone tumors in a tertiary care hospital of Dhaka city. Journal of Current and Advance Medical Research 2018;5(1):23-8.

7. Dabak N, Çıraklı A, Gülman B et al. Distribution and evaluation of bone and soft tissue tumors in the middle Black Sea Region. Acta Orthop Traumatol Turc 2014;48(1):17-24.

8. Erwteman AS, Balach T. Clinical evaluation and management of benign soft tissue tumors of the extremities. In: Peabody TD, Attar S, editors. Orthopaedic Oncology Primary and Metastatic Tumors of the Skeletal System. Chicago: Springer; 2014.p.171-203. 